Available online on 15.02.2020 at http://jddtonline.info
Open Access to Pharmaceutical and Medical Research
unrestricted non-commercial use, provided the original work is properly cited

Open 2 Access

Research Article

\title{
In-vitro Antioxidant and anti-inflammatory activities valorisation of tannin crude extract of Helianthemum helianthemoïdes (Desf.) Grosser
}

\author{
Nouioua Wafa ${ }^{* *}$ Gaamoune Sofiane $b$ \\ a: Faculty of Natural Life and Sciences, University Ferhat Abbas Setif, Algeria \\ b: National Institute of Agricultural Research - Setif - Algeria
}

\begin{abstract}
Plants have always been used by humans to relieve and cure many diseases unfortunately the majority of them still unknown. The aims of this study were to evaluate the antioxidant and anti-inflammatory properties of tannin crude extract of Helianthemum helianthemoïdes (Desf.) Grosser. The antioxidant activity was performed by DPPH radical scavenging method and the reducing power essay; however, the antiinflammatory activity was tested with the Human Red Blood Cell (HRBC) membrane stabilization method. The obtained results indicated high antioxidant potential and a perfect anti-inflammatory agent.
\end{abstract}

Keywords: Helianthemum helianthemoïdes; DPPH; reducing power; HRBC

Article Info: Received 29 Nov 2019; Review Completed 22 Jan 2020; Accepted 30 Jan 2020; Available online 15 Feb 2020



Cite this article as:

Wafa N, Sofiane G, In-vitro Antioxidant and anti-inflammatory activities valorisation of tannin crude extract of Helianthemum helianthemoïdes (Desf.) Grosser, Journal of Drug Delivery and Therapeutics. 2020; 10(1-s):135-139 http://dx.doi.org/10.22270/jddt.v10i1-s.3884

Nouioua Wafa, Faculty of Natural Life and Sciences, University Ferhat Abbas Setif, Algeria

\section{INTRODUCTION}

Helianthemum is a genus of plants including around 110 species of evergreen and semievergreen shrubs and belongs to the Cistaceae family also known as rock rose, the sun rose and rush rose. This genus can be found in America, Europe, and Northern Africa. However, the Mediterranean region is considered it's center of diversity [1].

Helianthemum helianthemoïdes (Desf.) Grosser., or Helianthemum Fontanesii B. et R., H. vulgare Pers. var. Fontanesii B. et T. is characterized by elliptical leaves, acute and revolted, up to $2.5 \mathrm{~cm}$ long. The upper face is very green and having, only, very long white hairs spread and a little scattered. The underface white tomentose felting very thick stellate hairs, with marked median nervure, ciliate and hispid. Pedicels and chalices bristling with long white hairs; those of the calyx located on the nervure and going from nervure to nervure or even longer. Intercostal parts of the calyx with thick foliage of yellowish starry hairs. Inflorescence shortly pedunculated, densiflora. Pedicels equaling approximately the chalices. Spatulate epicalice pieces are linear, very hirsute and twice as short as the sepals. Sepals oval and mucronate measured approximately $1 \mathrm{~cm}$. Petals yellow or white of about $1.2 \mathrm{~cm}$. Tomentose capsule, ovoid and much shorter than the calyx. Seeds compressed, finely granulated. This species grows on limestone rocks of low and medium mountains [2].

Some of the Helianthemum species are important medicinal plants used in several countries for different purposes [37]. This genus is reported to possess anti-inflammatory, antimicrobial, antiprotozoal and antioxidant properties [8 12]. Even if this genus was not studied much from the phytochemical viewpoint, some species have been previously examined for bioactive components like flavonoids, phenolic acids, lignans and essential oils [13 - 18].

Therefore, the goal of the present work was to determine the In-vitro Antioxidant and anti-inflammatory activities of this endemic species to enrich the Algerian pharmacopeia.

\section{MATERIAL AND METHODS}

\section{Plant material}

The random sampling was used during the harvesting. The areal parts of Helianthemum helianthemoïdes (Desf.) Grosser., were taken from the mountain of Megriss (X: $\mathbf{5}^{\circ} \mathbf{1 8}^{\prime}$ $20^{\prime \prime}$ and $X^{\prime}$ : $5^{\circ} 24^{\prime} 7^{\prime \prime}, Y: 36^{\circ} 18^{\prime} 30^{\prime \prime}$ and $Y^{\prime}: 36^{\circ} 21^{\prime} 54$ ). Determined in Laboratory of National Institute of Agricultural Research - Setif - Algeria. 


\section{Tannins extraction}

Powdered materials (10 g) were macerated in $100 \mathrm{~mL}$ of acetone $70 \%$ for 24 hours; the supernatant was then separated from the residue by filtration using Whatman no.1 filter paper and defatted by petroleum ether three times. The resultant fraction was concentrated and dried to a constant weight in a vacuum oven at $45^{\circ} \mathrm{C}$ and the residues obtained were stored in a refrigerator.

\section{Determination of Total Phenolic Content}

For total polyphenol determination, the Folin-Ciocalteu method was used [19]. The samples $(0.2 \mathrm{~mL})$ were mixed with $1 \mathrm{~mL}$ of the Folin-Ciocalteu reagent previously diluted with $10 \mathrm{~mL}$ of deionized water. The solutions were allowed to stand for 4 minutes at $25{ }^{\circ} \mathrm{C}$ before $0.2 \mathrm{~mL}$ of a saturated sodium carbonate solution $(75 \mathrm{mg} / \mathrm{mL})$ was added. The mixed solutions were allowed to stand for another 120 minutes before the absorbance at $765 \mathrm{~nm}$ was measured. Gallic acid was used as a standard for the calibration curve. The total phenolic compounds content was expressed as mg equivalent of Gallic acid per gram of extract (mg EAG/GE).

\section{DPPH Assay}

The donation capacity of extract was measured by bleaching of the purple colour solution of 1, 1-diphenyl-2picrylhydrazyl radical (DPPH) according to the method of Hanato et al., (1998) [20]. One millilitre of the extract at different concentrations was added to $0.5 \mathrm{~mL}$ of a DPPHmethanol solution. The mixtures was shaken vigorously and left standing at the laboratory temperature for 30 minutes in the dark. The absorbance of the resulting solutions were then measured at $517 \mathrm{~nm}$. The antiradical activity was expressed as IC $_{50}$ (micrograms per millilitre). The ability to scavenge the DPPH radical was calculated using the following equation:

$$
\text { DPPH scavenging effect }(\%)=\left[\left(A_{0}-A_{1}\right) / A_{0}\right] \times 100
$$

Where:

$\mathrm{A}_{0}$ : the absorbance of the control at 30 minutes.

$\mathrm{A}_{1}$ : is the absorbance of the sample at 30 minutes. BHT was used as standard [21].

\section{Reducing power}

The reducing power was determined according to the method of Oyaizu (1986) [22]. The extract at different concentrations $(2.5 \mathrm{~mL})$ was mixed with $2.5 \mathrm{~mL}$ of 200 $\mathrm{mmol} / \mathrm{L}$ sodium phosphate buffer (pH 6.6) and $2.5 \mathrm{~mL}$ of 10 $\mathrm{mg} / \mathrm{mL}$ potassium ferricyanide. The mixtures were incubated at $50{ }^{\circ} \mathrm{C}$ for 20 minutes; after cooling, $2.5 \mathrm{~mL}$ of $100 \mathrm{mg} / \mathrm{mL}$ trichloroacetic acid were added. The upper layer $(5 \mathrm{~mL})$ was mixed with $5 \mathrm{~mL}$ of deionized water and $1 \mathrm{~mL}$ of ferric chloride $(1 \mathrm{mg} / \mathrm{mL})$. The absorbance was measured at
$700 \mathrm{~nm}$ against a blank. A higher absorbance indicates a higher reducing power. $\mathrm{EC}_{50}$ value $(\mathrm{mg}$ extract $/ \mathrm{mL}$ ) is the effective concentration at which the absorbance was 0.5 for reducing power and was obtained by interpolation from the linear regression analysis. BHA was used as standard [23].

\section{The Human Red Blood Cell (HRBC) membrane stabilization method}

The HRBC suspension was prepared. The principle involved here was the stabilization of the human red blood cell membrane by hypo tonicity induced membrane lysis. The mixture contain $1 \mathrm{~mL}$ phosphate buffer (pH 7.4, $0.15 \mathrm{M}$ ), 2 $\mathrm{mL}$ hypo saline (0.36\%), $0.5 \mathrm{~mL}$ HRBC suspension (10\% $\mathrm{v} / \mathrm{v}$ ) and $0.5 \mathrm{~mL}$ of the plant extract or the standard drug (diclofenac sodium) at various concentrations $(10,50,100$, $250,500 \mu \mathrm{g} / \mathrm{mL}$ ). The control was distilled water instead of hypo saline to produce $100 \%$ haemolysis.

The mixtures were incubated at $37{ }^{\circ} \mathrm{C}$ for 30 minutes and centrifuged at $2500 \mathrm{rpm}$ for 5 minutes. The absorbance of haemoglobin content in the suspensions was estimated at $560 \mathrm{~nm}$. The percentage of haemolysis of HRBC membrane can be calculated as follows:

Hemolysis (\%) = (Optical density of Test sample / Optical density of Control) $\times 100$

However, the percentage of HRBC membrane stabilization can be calculated as follows:

Protection (\%) = $100-[($ Optical density of Test sample $/$ Optical density of Control) $\times$ 100] [24].

\section{Statistical analysis}

Results were expressed as the mean \pm standard deviation. Data was statistically analysed using $t$ test of Student as primary test followed by Fisher test with the criterion of $\mathrm{P}<$ 0.05 to determine whether there were any significant differences between tannins crude extract of Helianthemum helianthemoïdes (Desf.) Grosser., and standards, using Graphpad prism 5 Demo Software.

\section{RESULTS AND DISCUSSION}

The results revealed that phenolic content was $69,94 \pm 2,77$ mg EAG/GE. Polyphenols help in protecting cells against oxidative damage caused by free radicals due to their redox properties, which enable them to act as reducing agents, hydrogen donors and singlet oxygen quencher [17].

The hydrogen atoms or electron donation ability of the extract was measured from the bleaching of purple colour of methanol solution of DPPH [25]. Figure 1 shows the doseresponse curve of DPPH radical scavenging activity of tannin crude extract of Helianthemum helianthemoïdes, compared with BHT. 


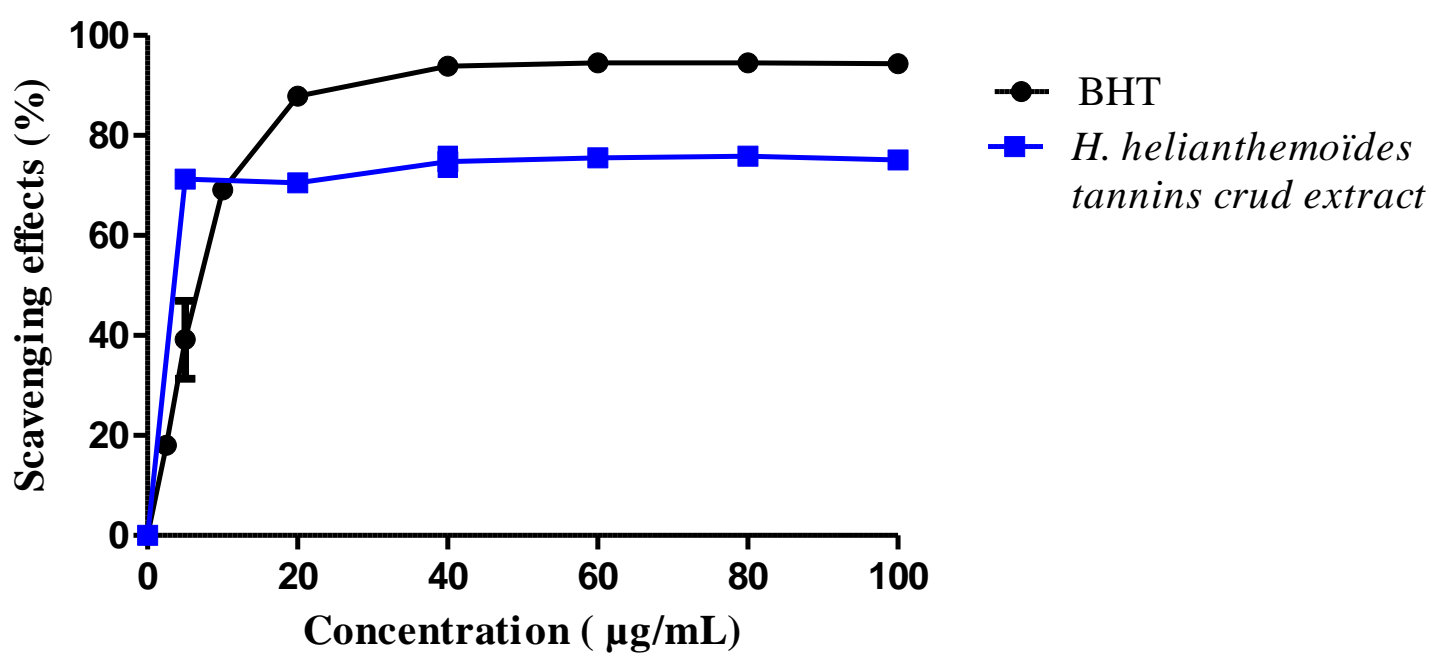

Figure 1: DPPH test of tannins crude extract of Helianthemum helianthemoïdes (Desf.) Grosser

The percentage of scavenging activity and IC50 value of extract were found to be $73,51 \pm 0,95 \%$ and $1,56 \pm$ $0,55 \mu \mathrm{g} / \mathrm{mL}^{* * *}$ respectively against $99,50 \pm 0,01 \%$ and $8,76 \pm, 69 \mu \mathrm{g} / \mathrm{mL}$ for BHT. These findings suggested that there could be a correlation between the antioxidant activity and phenolic compounds; and Several authors [26, 27] have well and widely studied their antioxidant properties.
The reducing capacity of a compound may serve as a significant indicator of its potential antioxidant activity [28]. Figure 2 shows the dose response curves for the reducing powers of tannins crude extract of Helianthemum helianthemoïdes:

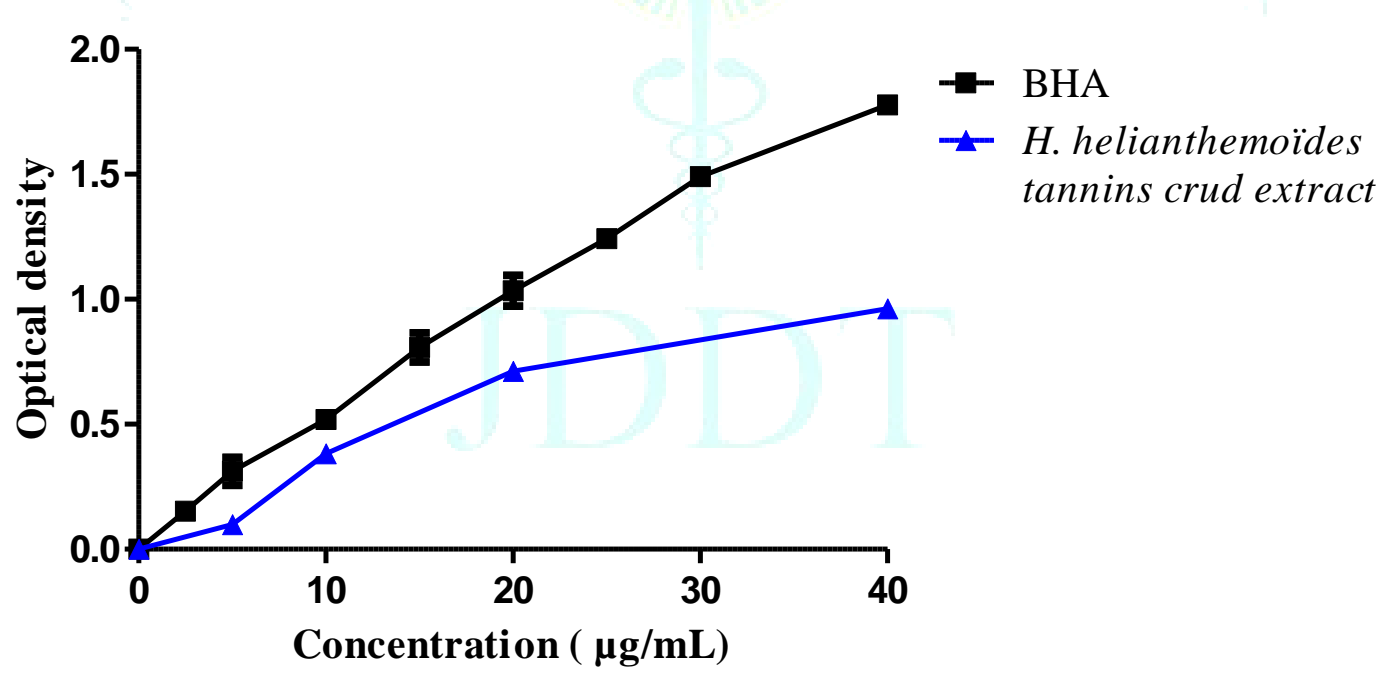

Figure 2: Reducing power activity of tannins crude extract of Helianthemum helianthemoïdes (Desf.) Grosser

It was found that the reducing power increased with the concentration of the sample estimated important, but it still weaker than the standard with $\mathrm{EC}_{50}$ of $17,53 \pm 0,57 \mu \mathrm{g} / \mathrm{mL}^{* * *}$ against $9,03 \pm 0,62 \mu \mathrm{g} / \mathrm{mL}$ for the ascorbic acid.
The human erythrocyte membrane lysis induced by a hypotonic solution was used to measure the antiinflammatory potential of tannins crude extract of Helianthemum helianthemoïdes. Figure 2 demonstrated the ability of the extract to inhibit lysis induced by water. 


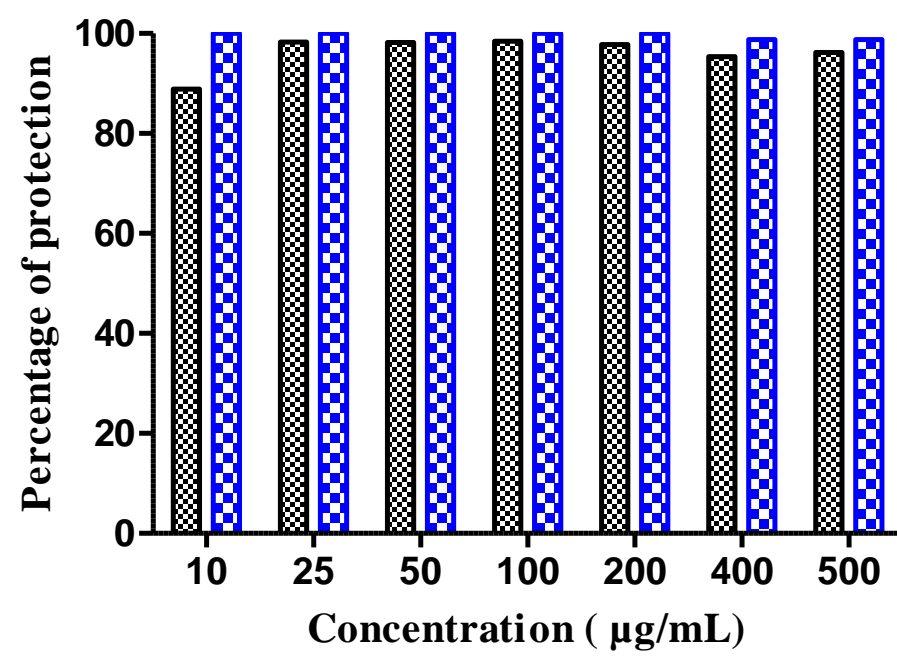

\% Declofenac Sodium

H.helianthemoïdes tannins crud extract

Figure 3: The percentage inhibition of hypotonicity induced hemolysis of HRBCs (\%) of standard and tannins crude extract of Helianthemum helianthemoïdes (Desf.) Grosser.

The erythrocyte membrane resembles lysosomal membrane and as such, the erythrocyte could be extrapolated to the stabilization of the lysosomal membrane [29]. The vitality of cells depends on the integrity of their membranes, exposure of RBC's to injurious substances such as hypotonic medium [30]. Tannins crude extract of Helianthemum helianthemoïdes shows a high percentage of protection against hemolysis reach $100 \%$. This is in line with the report of Ahmadiani et al., [31] who stated that flavonoids as well as tannins possess anti-inflammatory effects.

\section{CONCLUSION}

To the best our knowledge, Helianthemum helianthemoïdes was studied for the first time. It was found that tannins crude extract of this species possesses a potent antioxidant and anti-inflammatory activities estimated to be perfect. The tannins crude extract of Helianthemum helianthemoïdes has shown the presence of an important quantity of polyphenols that may be responsible for the antioxidant and RBC membrane stabilization activities. Additional studies are needed to characterize the active compounds and to clarify the in vivo potential of this plant.

\section{REFERENCES}

[1] Mabberly DJ. The plant book. Cambridge university press, Cambridge. 1997.

[2] Quézel P, Santa S. New flora of the Algeria and southern desert regions]. Paris: National Centre for Scientific Research; French. 1963; 2:571- 738.

[3] Meckes M.; Torres J.; Calzada F.; Rivera J.; Camorlinga M.; Lemus H.; Rodríguez G. Antibacterial properties of Helianthemum glomeratum, a plant used in Maya traditional medicine to treat diarrhea. Phytother. Res. 1997; 11:128-131.

[4] Rubio-Moraga Á.; Argandoña J.; Mota B.; Pérez J.; Verde A.; Fajardo J.; Gómez-Navarro J.; Castillo-López R.; Ahrazem O.; Gómez-Gómez, L. Screening for polyphenols, antioxidant and antimicrobial activities of extracts from eleven Helianthemum taxa (Cistaceae) used in folk medicine in south-eastern Spain. J. Ethnopharmacol. 2013; 148:287-296.

[5] Meckes M.; Villarreal M.L.; Tortoriello J.; Berlin B.; Berlin E.A. A microbiological evaluation of medicinal plants used by the Maya people of Southern Mexico. Phytother. Res. 1995; 9:244-250.

[6] Calzada F.; Alanís A.D.; Meckes M.; Tapia-Contreras A.; CedilloRivera R. In vitro susceptibility of Entamoeba histolytica and
Giardia lamblia to some medicinal plants used by the people of Southern Mexico. Phytother. Res. 1998; 12:70-72.

[7] Rigat M.; Bonet M.A.; Garcia S.; Garnatje T.; Vallès J. Studies on pharmaceutical ethnobotany in the high river Tervalley (Pyrenees, Catalonia, Iberian Peninsula). J. Ethnopharmacol. 2007; 113:267-277.

[8] Meckes M.; Calzada F.; Tapia-Contreras A.; Cedillo-Rivera R. Antiprotozoal propertiesof Helianthemum glomeratum. Phytother. Res. 1999; 13:102-105.

[9] Barbosa E.; Calzada F.; Campos R. Antigiardial activity of methanolic extracts from Helianthemum glomeratum Lag. and Rubus coriifolius Focke in suckling mice CD-1. J. Ethnopharmacol. 2006; 108:395-397.

[10] Tawaha K.; Alali F.Q.; Gharaibeh M.; Mohammad M.; El-Elimat T. Antioxidant activity and total phenolic content of selected Jordanian plant species. Food Chem. 2007; 104:1372-1378.

[11]. Bouzergoune, F.; Bitam, F.; Aberkane, M.C.; Mosset, P. Preliminary phytochemical and antimicrobial activity investigations on the aerial parts of Helianthemum kahiricum. Chem. Nat. Compd. 2013; 49:751-752.

[12]. Alsabri S.G.; Rmeli N.B.; Zetrini A.A.; Mohamed S.B.;Meshri M.I.; Aburas K.M.; Bensaber S.M.;Mrema I.A.; Mosbah A.A.; Allahresh, K.A.; et al. Phytochemical, anti-oxidant, anti-microbial, antiinflammatory and anti-ulcer properties of Helianthemum lippii. J. Pharmacogn. Phytochem. 2013; 2:86-96.

[13]. Benabdelaziz I.; Marcourt L.; Benkhaled M.; Wolfender J.L.; Haba H. Antioxidant and antibacterial activities and polyphenolic constituents of Helianthemum sessiliflorum Pers. Nat. Prod. Res. 2016; 15:686-690.

[14]. Calzada F.; Alanis A.D. Additional antiprotozoal flavonol glycosides of the aerial parts of Helianthemum glomeratum. Phytother. Res. 2007; 21:78-80.

[15]. Barbosa E.; Calzada F.; Campos, R. In vivo antigiardial activity of three flavonoids isolated of some medicinal plants used in Mexican traditional medicine for the treatment of diarrhea. J. Ethnopharmacol. 2007; 109:552-554.

[16]. Benabdelaziz I.; Haba H; Lavaud C.; Harakat D.; Benkhaled M. Lignans and other constituents from Helianthemum sessiliflorum Pers. Rec. Nat. Prod. 2015; 9:342-348.

[17]. Calzada F, Lopez R, Meckes M, Cedillo-Rivera R. Flavonoids of the aerial parts of Helianthemum glomeratum. Int. J. Pharmacogn. 1995; 33:351-352. 
[18] Javidnia K, Nasiri A, Miri R, Jamalian A. Composition of the essential oil of Helianthemum kahiricum Del. from Iran. J. Essent. Oil Res. 2007; 19:52-53.

[19] Li WD, Wei C L, White P J, Beta T, High-amylose corn exhibits better antioxidant activity than typical and waxy genotypes. Journal of Agricultural and Food Chemistry, 2007; 55:291-298.

[20] Hanato T, Kagawa H, Yasuhara T, Okuda T, Two new flavonoids and other constituents in licorice root: Their relative astringency and radical scavenging effects. Chemical \& Pharmaceutical Bulletin, 1998; 2090-2097.

[21] Bettaieb RI, Bourgou S, Ben SlimenDebez I, JabriKaroui I, Hamrouni Sellami I, Msaada K, Limam F, Marzouk B, Food Bioprocess Techno., 2011, 1007.

[22] Oyaizu M. Studies on products of browningreactions: antioxidative activities of products of browning reaction prepared from glucosaminutese, Japanese Journal of Nutrition, 1986: 307-315.

[23] Huang SJ, Mau JL. Antioxidant properties of methanolic extracts from Agaricusblazei with various doses of $y$-irradiation. Swiss Society of Food Science and Technology 2006; 39:707-716.

[24] Seema CC ., Sharan SV, Srinivasa RB, Meena V, In vitro antiinflammatory activity of Methanolic extract of Centellaasiatica by HRBC Membrane stabilization. Rasayan journal of chemistry, 2011; 4(2):457-460.

[25] Bicha S, Amrani A, Benaissa O, León F, Zama D, Brouard I, Benayache S, Bentamene A, Benayache F. A flavonoid with high antioxidant effect from Centaurea acaulis L. Der Pharmacia Lettre 2013; 5(6):24-30.

[26] Pietta PG, Flavonoids as antioxidants. J Nat Prod 2000; 63:1035-1042.

[27] Candan F, Unlu M, Tepe B, Daferera D, Polissiou M, So“kmen A Akpulat HA, Antioxidant and antimicrobial activity of the essential oil and methanol extracts of Achillea millefolium subsp. millefolium Afan. (Asteraceae). J Ethnopharmacol 2003; 87:215-220

[28]Chung YC, Chang CT, Chao WW, Lin CF, Chou ST. Antioxidative activity and safety of the $50 \%$ ethanolic extract from red bean fermented by Bacillus subtilis IMR-NK1. Journal of Agriculture and Food Chemistry. 2002; 50:2450-2454.

[29] Omale J, Okafor PN, Comparative antioxidant capacity and cytotoxicity of the leaf and stem of Cissus multistriata. African Journal of Biotechnology., 2008; 7(17):3129-3133.

[30] Augusto O., Kunze KL., Montellano PR.: N phenylprotoporphyrin formation in the haemoglobin phenylhydrazine reaction. J ournal of Biological Chemistry 1982; $257(11): 6231-6241$.

[31] Ahmadiani A, Hosseiny J, Semnanian S, Javan M, Saeedi F, Kamalinejad M, Serami S. Antinociceptive and Antiinflammatory effects of Elaeagnus angustifolia fruits extract. J Ethnopharmacol. 2000; 72:287-292. doi: 10.1016/S03788741(00)00222-1. 